\title{
Efektivitas Penerapan E-Modul dalam Meningkatkan Pemahaman Siswa Kelas VIII pada Materi Pola Bilangan Masa Pandemi
}

Author:
Sayekti Nur Puspitasari ${ }^{1}$
Suyono $^{1}$
Erika Laras Astutiningtyas ${ }^{1}$
Affiliation:
${ }^{1}$ Mathematics Education,
University of Veteran Bangun
Nusantara, Central Java,
Indonesia

Corresponding author:
Sayekti Nur Puspitasari,
Sayektipuspita0628@gmail.co
m
Dates:
Received: $7 / 10 / 2021$
Accepted: $21 / 11 / 2021$
Published: $30 / 11 / 2021$

\begin{abstract}
Abstrak. Pelaksanaan pembelajaran online menjadi tantangan bagi para guru matematika dalam memberikan materi pola bilangan kepada siswa. E-Modul merupakan salah satu media yang dapat digunakan untuk mendukung pembelajaran secara online. Penelitian ini bertujuan untuk mengetahui langkah-langkah pembuatan E-Modul dan efektivitas penerapan E-Modul dalam meningkatkan pemahaman siswa. Penelitian ini merupakan penelitian kualitatif. Teknik pengumpulan data yang digunakan yaitu metode angket dan wawancara. subjek penelitian siswa kelas VIII SMP N 2 Tawangsari. Hasil dari penelitian menunjukan bahwa persentase rata-rata tiap aspek respon siswa terhadap penerapan E-Modul dalam meningkatkan pemahaman siswa kelas VIII pada materi pola bilangan termasuk dalam kategori baik, yang artinya para siswa setuju dengan adanya penerapan E-Modul dalam meningkatkan pemahaman pada materi pola bilangan.
\end{abstract}

Kata kunci: E-Modul, Pola Bilangan, Pemahaman
Abstract. The implementation of online learning is a challenge for mathematics teachers in providing number pattern material to students. EModul is one of the media that can be used to support online learning. This study aims to determine the steps of making E-Modules and the effectiveness of implementing E-Modules in improving students' understanding. This research is a qualitative research. Data collection techniques used questionnaires and interviews. The research subjects were VIII grade students of SMP N 2 Tawangsari. The results of the study show that the average percentage of each aspect of student responses to the application of $E$ Modules in improving students' understanding of class VIII on number pattern material is included in the good category, which means that students agree with the application of E-Modules in improving understanding of pattern material. number.

Keywords: E-Modules, number pattern, understanding

\section{J0M \\ This work is licensed under a Creative Commons Attribution-ShareAlike 4.0 International License. \\ Read online: \\ https://jurnal.unej.ac.id/index.php/JOMEAL/index or scan barcode beside.}

How to cite this article:

Puspitasari, S., Suyono, S., \& Astutiningtyas, E. (2021). Efektivitas Penerapan E-Modul dalam Meningkatkan Pemahaman Siswa Kelas VIII pada Materi Pola Bilangan Masa Pandemi. Journal of Mathematics Education and Learning, 1(3), 274-286. doi:10.19184/jomeal.v1i3.26773 


\section{Pendahuluan}

Perubahan sistem pembelajaran yang disebabkan karena terjadinya pandemi covid-19 di Indonesia menjadi tantangan tersendiri bagi para guru dan siswa. Para siswa yang biasanya mendapatkan pembelajaran di kelas dan menerima penjelasan materi-materi beserta tugas dari para guru dengan tatap muka, kini dituntut untuk mampu belajar secara mandiri, baik dalam mencari referensi yang mendukung dan memahami materi-materi tentang berbagai mata pelajaran untuk menyelesaikan tugas yang diberikan oleh guru secara online. Para guru dituntut memberikan pembelajaran dengan metode-metode yang bisa dilaksanakan secara online dengan memanfaatkan media pembelajaran seadanya. Banyak kendala yang terjadi disaat pembelajaran online dilaksanakan secara tiba-tiba. Tidak mendukungnya fasilitas dan jaringan menjadi faktor utama yang mempengaruhi dalam pelaksanaan pembelajaran secara online. Selain itu, kurangnya fasilitas yang mendukung saat pembelajaran, juga menyebabkan menurunnya pemahaman siswa terhadap materi yang disampaikan. Banyaknya kendala saat pembelajaran online, membuat para guru sedikit kewalahan saat memberikan pembelajaran kepada para siswa. Untuk mendukung terlaksananya pembelajaran online para guru pada umumnya menggunakan aplikasi Zoom, Google Classroom, dan grup whatsapp dalam menyampaikan materi dan tugas-tugas (Naserly, 2020).

Salah satu mata pelajaran yang cukup dianggap sulit dengan diterapkannya pembelajaran secara online yaitu matematika. Matematika merupakan mata pelajaran yang diajarkan dari Sekolah Dasar hingga Sekolah Menengah Atas. Mata pelajaran matematika merupakan mata pelajaran yang berfungsi untuk mengembangkan kemampuan menghitung, mengukur, menurunkan dan menggunakan rumus matematika yang diperlukan dalam kehidupan sehari-hari (Nur, 2013). Materi pada pembelajaran matematika sangat banyak, salah satunya adalah materi pola bilangan. Menurut (Marion et al., 2015) Pola bilangan merupakan salah satu pembelajaran matematika yang dapat mengembangkan kemampuan berpikir siswa. Maka dari itu perlunya mata pelajaran pola bilangan sebagai pembelajaran yang melatih nalar siswa. Peningkatan pemahaman serta semangat para siswa dalam belajar pada materi pola bilangan tersebut perlu dengan bantuan media pembelajaran yang mendukung dan efektif. Modul merupakan salah satu media pembelajaran yang bisa digunakan oleh para tenaga guru dalam membantu dan sebagai media pendukung dalam pembelajaran online saat ini. (Satriawati, 2015) mengemukakan modul dapat menfasilitasi siswa dalam belajar mandiri maupun konvensional dan juga modul dilengkapi petunjuk untuk belajar sendiri, sehingga siswa dapat belajar sesuai dengan kemampuannya dan dapat memenuhi seluruh kompetensi yang harus dikuasai oleh siswa. Modul juga dapat dikembangkan menjadi media interaktif berbasis teknologi (E-Modul) sehingga dapat diakses oleh para siswa di masa pandemi covid-19 ini.

Berdasarkan uraian tersebut, maka munculah keinginan peneliti untuk mengadakan penelitian mengenai penerapan e-modul pada siswa kelas VIII SMP N 2 Tawangsari dengan tujuan untuk mengetahui langkah - langkah pembuatan E-Modul serta efektivitas penerapan E-Modul dalam meningkatkan pemahaman siswa. Oleh karena itu diangkat sebuah judul efektivitas penerapan EModul dalam meningkatkan pemahaman siswa kelas VIII pada materi pola bilangan di masa pandemi covid-19. 


\section{Metode Penelitian}

Penelitian ini merupakan penelitian deskriptif kualitatif. Tempat pelaksanaan penelitian ini adalah SMP N 2 Tawangsari, dengan subjek penelitian kelas VIII pada waktu bulan Maret sampai bulan Juli 2021. Metode pengumpulan data menggunakan metode angket dan metode wawancara. Pada metode angket, pengukuran angket dengan menggunakan skala likert. Skala likert digunakan untuk mengukur sikap, pendapat, dan persepsi seseorang atau sekelompok orang tentang fenomena sosial (Sugiyono, 2018:146). Dalam penelitian ini menggunakan pertanyaan tertutup bernilai positif. Alternatif jawaban yang diberikan yaitu Sangat Setuju (SS), Setuju (S), Tidak Setuju (TS), Sangat Tidak Setuju (STS). Adapun pemberian skor pada tiap item adalah sebagai berikut:

Tabel 1. Bobot Penyekoran Jawaban Pada Angket

\begin{tabular}{|c|c|}
\hline Alternatif Jawaban & Skor \\
\hline Sangat Setuju & 4 \\
\hline Setuju & 3 \\
\hline Tidak Setuju & 2 \\
\hline Sangat Tidak Setuju & 1 \\
\hline
\end{tabular}

Pemberian angket pada penelitian ini secara online melalui google form dengan kisi - kisi sebagai berikut :

Tabel 2. Kisi - Kisi Instrumen Angket

\begin{tabular}{|c|l|}
\hline Aspek Penilaian & \multicolumn{1}{|c|}{ Indikator } \\
\hline Kegunaan & a) Mempermudah dan meningkatkan pemahaman \\
& bada materi pembelajaran \\
& b) Memberikan fokus perhatian pada siswa \\
& c) Membantu proses pembelajaran \\
\hline Kemudahan & a) Penggunaan E-Modul mudah dipelajari \\
pengguna & b) Pengaksesan E-Modul dapat dengan mudah \\
\hline Tampilan media & a) Tampilan \\
\hline bepuasan siswa & a) Ukuran \\
\hline Materi & b) bedia pendukung pembelajaran daring \\
& a) kesesuaian materi \\
\hline & b) gambar mudah terbaca \\
\hline
\end{tabular}

Sedangkan pada metode wawancara digunakan untuk mendapatkan informasi yang nantinya hasil dari wawancara dapat menjadi bahan perbandingan dengan hasil angket. Penentuan jumlah siswa yang diwawancarai berdasarkan pada pendapat Gay dan Diehl (dalam Alfalathi, Fanzy, and Muharomah 2020) menuliskan yakni untuk penelitian deskriptif, penentuan jumlah sampel 10\% dari populasi. Dalam penelitian ini, jumlah respondennya adalah 32 responden. Maka, untuk jumlah sampel yang diwawancarai adalah 10\% dari 32 responden yaitu 3,2 atau kurang lebih 4 siswa. Teknik pengambilan sampel menggunakan teknik sampling purposive atau pertimbangan tertentu dari peneliti dan dilanjutkan dengan random sampling dengan teknik undian. Untuk kisi - kisi metode wawancara sebagai berikut: 
Tabel 3. Kisi - Kisi Instrumen Wawancara

\begin{tabular}{|l|l|l|}
\hline \multicolumn{1}{|c|}{ No } & \multicolumn{1}{|c|}{ Aspek } & \multicolumn{1}{c|}{ Bentuk Pertanyaan/ Subjek } \\
\hline 1. & $\begin{array}{l}\text { Penggunaan E-Modul dalam } \\
\text { pembelajran pola bilangan }\end{array}$ & $\begin{array}{l}\text { Siswa } \\
\text { Bagaimana tanggapan anda mengenai } \\
\text { penggunaan E-Modul dalam kegiatan pembelajaran pada materi } \\
\text { pola bilangan? }\end{array}$ \\
\hline 2. & Tampilan E-Modul & $\begin{array}{l}\text { Siswa } \\
\text { Menurut anda, apakah penggunaan E-Modul dalam pembelajaran } \\
\text { mudah? }\end{array}$ \\
\hline $\begin{array}{l}\text { Apakah anda merasa keberatan saat pembelajaran menggunakan } \\
\text { E-Modul? }\end{array}$ \\
\hline 4. & Materi & $\begin{array}{l}\text { Menurut anda, Bagaimana tampilan E-Modul pada materi pola } \\
\text { bilangan? }\end{array}$ \\
\hline & $\begin{array}{l}\text { Siswa } \\
\text { Menurut anda, apakah penggunaan E-Modul dapat membantu } \\
\text { anda dalam memahami materi pola bilangan selama pembelajaran } \\
\text { di masa pandemi? }\end{array}$ \\
\hline
\end{tabular}

Teknik analisis data pada penelitian ini melalui tiga tahapan yaitu reduksi data, penyajian data dan penarikan kesimpulan. Menurut Riduwan (dalam Prasetyo 2017) Untuk menganalisis data hasil angket respon siswa dapat dihitung dan dapat dinterpretasikan dengan cara berikut ini :

$$
P \%=\frac{\sum F}{N \times I \times R} \times 100 \%
$$

Keterangan:

$\mathrm{P}(\%)=$ hasil persentase

$\sum \mathrm{F}=$ jumlah skor

$\mathrm{N}=$ skor tertinggi

I = jumlah indikator/aspek/pernyataan

$\mathrm{R}=$ banyaknya responden

Tabel 4. Interpretasi Respon Siswa

\begin{tabular}{|c|c|}
\hline Presentase & Kategori \\
\hline $0-20 \%$ & Sangat Kurang Baik \\
\hline $21-40 \%$ & Kurang Baik \\
\hline $41-60 \%$ & Cukup Baik \\
\hline $61-80 \%$ & Baik \\
\hline $81-100 \%$ & Sangat Baik \\
\hline
\end{tabular}

Prosedur pelaksanaan penelitian efektivitas penerapan E-Modul dalam meningkatkan pemahaman pada pembelajaran pola bilangan kelas VIII adalah sebagai berikut: 


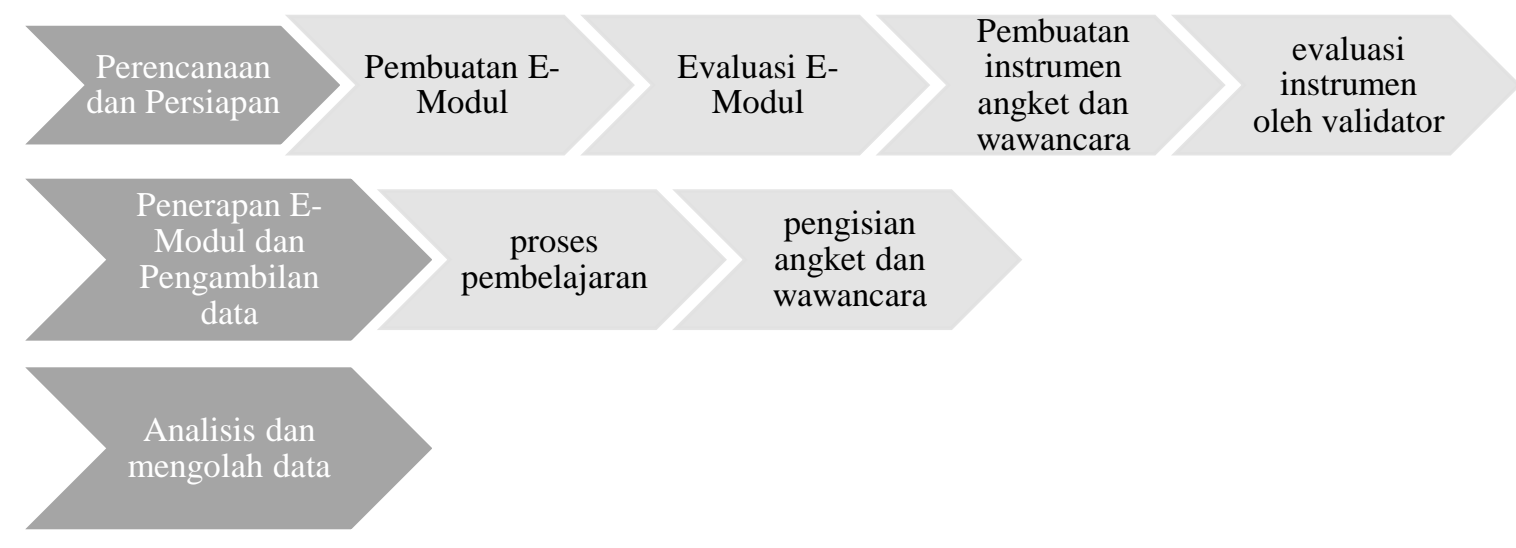

Gambar 1. Prosedur Pelaksanaan Penlitian

Penelitian ini menggunakan triangulasi teknik, yaitu dengan membandingkan data hasil penelitian dengan data hasil wawancara terhadap siswa kelas VIII. Dari hasil perbandingan tersebut bisa saja terjadi perbedaan pandangan, pendapat atau pemikiran, sehingga dengan mengfgunakan teknik triangulasi teknik ini berguna untuk mengetahui penyebab terjadinya perbedaan tersebut.

\section{Hasil dan Pembahasan}

\section{Langkah Pembuatan E-Modul Dengan Materi Pola Bilangan Yang Bisa Diterapkan Di Masa Pandemi Covid-19}

Pembuatan E-Modul sebagai bahan ajar dengan materi pola bilangan yang bisa diterapkan di masa pandemi covid-19 harus menyesuaikan kebutuhan dan kondisi siswa sebagaimana menurut Depdiknas (dalam Utami et al., 2018) tujuan pengembangan bahan ajar ialah Menyediakan bahan ajar yang sesuai dengan tuntutan kurikulum dengan mempertimbangkan kebutuhan siswa, yakni bahan ajar yang sesuai dengan karakteristik dan setting atau lingkungan sosial siswa. Pada penelitian ini pembuatan E-Modul melalui tiga tahap dari tahapan tersebut. Berikut langkah - langkah pembuatan E-Modul dalam penelitian ini.

Tahap Pendefinisian terdiri dari tiga analisis, yaitu analisis peserta didik, analisis materi, analisis tugas dan analisis tujuan pembelajaran. Berikut penjelasan dari ke empat analisis tersebut:

Analisis Peserta didik, analisis ini dilakukan untuk mengetahui sejauh mana keaktifan siswa dalam pembelajaran secara daring. Pada peserta didik melalui metode wawancara dengan guru pengampu mata pelajaran matematika diperoleh hasil bahwa para siswa kelas VIII sudah mengenal dan bisa mengoperasikan media teknologi pendukung pembelajaran seperti HP/Laptop, hal ini dibuktikan dengan keikutsertaan para siswa dalam pelaksanaan pembelajaran jarak jauh dan kegiatan PAT. Pada saat melaksanakan pembelajaran daring 80\% siswa dapat mengikuti secara aktif dan $20 \%$ siswa terkendala mengikuti pembelajaran dikarenakan kurangnya fasilitas media teknologi.

Analisis Materi, analisis materi ini digunakan untuk meninjau materi yang akan dimuat dalam E-Modul. Berdasarkan hasil wawancara dengan guru pengampu pada analisis materi untuk awal semester ganjil, materi yang diberikan kepada siswa adalah pola bilangan. Dari guru pengampu pembelajaran mengatakan bahwa ada beberapa kesulitan saat mengajarkan materi pola bilangan di masa pandemi, misalnya dalam memberikan contoh pola harus disesuaikan dengan kondisi sehingga siswa benar - benar paham tentang materi tersebut. 
Analisis tugas dilakukan untuk meninjau penugasan yang diberikan oleh guru pengampu. Melalui wawancara dengan guru pengampu, dari hasil wawancara guru memberikan tugas rangkuman setelah pembelajaran. Hal itu dilakukan untuk mengetahui kemampuan siswa dalam memahami materi pembelajaran. Tugas diberikan lewat aplikasi Google Classroom, Google form, dan Whatsapp.

Analisis tujuan dilakukan untuk meninjau tujuan pembelajaran pada masa pandemi covid-19. Analisis ini dilakukan dengan peneliti mencari referensi melalui buku dan internet mengenai tujuan dari pembelajaran pada materi pola bilangan. Selain itu pembuatan E-Modul ini bertujuan untuk media pembantu saat pembelajaran daring.

Tahap Perancangan terdiri dari tiga prosedur yaitu : pemilihan media, pemilihan dan perancangan format, evaluasi. Pada langkah pemilihan media, Menurut (Abidin, 2016) dalam pemilihan media terdapat beberapa prinsip yang harus diperhatikan yaitu adanya kejelasan maksud dan tujuan pemilihan media, adanya familiaritas media, ada sejumlah media pembelajaran yang dapat dipilih atau diperbandingkan, ada sejumlah kriteria atau norma yang dipakai dalam proses pemilihan. Pada penelitian ini pemilihan media menggunakan prinsip tersebut sehingga terpilihnya media berupa E-Modul yang disusun melalui fliping book online.

Perancangan format pada E-Modul harus menarik agar nantinya dapat menambah motivasi belajar dan meningkatkan pemahaman siswa sebagaimana pendapat dari (Mahnun, 2012) pemilihan media melalui tiga kriteria yaitu kelayakan praktis, kelayakan teknis dan kelayakan biaya. Pada kelayakan teknis ada dua macam kualitas yang dipertimbangkan yaitu kualitas pesan (kurikulum) dan kualitas visual. Dalam pembuatan E-Modul ini tentu saja pembuatannya harus memperhatikan sasaran pembelajaran, kejelasan dalam struktur materi yang dijabarkan sehingga mudah dipahami dan tampilan yang menarik.

Langkah evaluasi dilakukan dengan memberikan lembar penilaian kepada ahli media dan ahli materi yang sesuai dengan isi E-Modul untuk mendapatkan kritik dan saran. Pada umumnya para evaluator menyatakan kelayakan E-Modul untuk pembelajaran disertai dengan revisi untuk media tersebut. Dari para evaluator yang terdiri dari ahli media dan ahli materi memberikan komentar sebagai berikut.

Tabel 5. Kritik dan Saran Evaluator

\begin{tabular}{|c|l|}
\hline Evaluator & \multicolumn{1}{|c|}{ Komentar } \\
\hline Ahli Media & Untuk tampilan dan kemudahan sudah baik. \\
\hline Ahli Materi & $\begin{array}{l}\text { Hendaknya E-Modul perlu adanya tambahan } \\
\text { evaluasi kepada siswa, untuk keseluruhan } \\
\text { sudah bagus. }\end{array}$ \\
\hline
\end{tabular}

Tahap penyebaran E-Modul pada penelitian ini dilakukan pada saat pembelajaran oleh guru pengampu mata pelajaran matematika kelas VIII di sekolah SMP N 2 Tawangsari dengan cara menyebarkan link E-Modul kepada siswa melalui Google Classroom dan whatsapp chat

Pembuatan E-Modul pada penelitian ini sejalan dengan pendapat dari Thiagarajan (dalam Utami et al., 2018) Prosedur pengembangan E-Modul menggunakan model 4-D (Four D model) 
terdiri dari 4 tahapan, yaitu: (1) pendefinisian (define), (2) perancangan (design), (3) pengembangan (develop), (4) tahap penyebaran (desseminate).

\section{Penerapan E-Modul Dalam Meningkatkan Pemahaman Siswa Kelas VIII SMP N 2 Tawangsari Pada Materi Pola Bilangan Di Masa Pandemi Covid-19}

Pengumpulan data pada penelitian ini menggunakan angket dan wawancara. Pada metode angket terdiri dari lima aspek yaitu kegunaan, kemudahan pengguna, tampilan media, kepuasan siswa, dan materi. Pada setiap aspek memiliki lima pernyataan yang digunakan untuk menganalisis keefektifan penerapan E-Modul pada proses pembelajaran. Berdasarkan hasil perhitungan, diperoleh persentase rata - rata setiap aspek sebagai berikut:

Tabel 6. Persentase Rata - Rata Hasil Angket efektivitas Penerapan E-Modul

\begin{tabular}{|l|l|l|l|l|}
\multicolumn{1}{c|}{ Aspek } & $\begin{array}{c}\text { Jumlah } \\
\text { Skor }\end{array}$ & $\begin{array}{c}\text { Skor } \\
\text { Kriterium }\end{array}$ & P \% & Kategori \\
\hline Kegunaan & 446 & 640 & 69,69 & Baik \\
\hline $\begin{array}{l}\text { Kemudahan } \\
\text { Pengguna }\end{array}$ & 424 & 640 & 66,25 & Baik \\
\hline Tampilan Media & 439 & 640 & 68,59 & Baik \\
\hline Kepuasan Siswa & 451 & 640 & 70,47 & Baik \\
\hline Materi & 448 & 640 & 70,00 & Baik \\
\hline
\end{tabular}

Berdasarkan paparan hasil penelitian angket dan wawancara menunjukan bahwa keefektivan penerapan E-Modul dalam meningkatkan pemahaman siswa kelas VIII SMP N 2 Tawangsari pada materi pola bilangan di masa pandemi covid-19 dapat dilihat dari 5 aspek, yaitu aspek kegunaan, aspek kemudahan pengguna, aspek tampilan media, aspek kepuasan siswa dan aspek materi.

Hasil penelitian angket pada aspek kegunaan terdiri dari lima pernyataan dengan tiga indikator, pada pernyataan pertama termasuk dalam pernyataan positif yaitu penggunaan EModul mempermudah dan meningkatkan pemahaman saya pada materi pola bilangan. Pada pernyataan tersebut respon 32 siswa kelas VIIIC termasuk dalam kategori baik yaitu sebesar $74,22 \%$. Berdasarkan hasil angket tersebut menunjukan bahwa para siswa setuju dengan penggunaan E-Modul dalam pembelajaran materi pola bilangan. Pada pernyataan yang kedua yaitu Saya mengalami kesulitan untuk mendalami materi pola bilangan melalui E-Modul. Pada pernyataan ini termasuk dalam pernyataan negatif, dengan persentase respon siswa sebesar $60,94 \%$ dan persentase tersebut masuk dalam kategori cukup baik. Berdasarkan hasil tersebut menunjukan bahwa sebagian besar para siswa tidak setuju dengan pernyataan tersebut. Pada pernyataan yang ketiga yaitu Penggunaan E-Modul memberikan fokus perhatian bagi saya sehingga saya lebih fokus memahami materi pola bilangan. Pernyataan tersebut mendapatkan persentase dengan kategori baik yaitu sebesar 72,66\%. Berdasarkan persentase tersebut menunjukan bahwa para siswa setuju dengan pernyataan tersebut. Pada pernyataan keempat yaitu Penggunaan E-Modul tidak membantu proses pembelajaran saat pandemi Covid-19. Berdasarkan pernyataan tersebut pada hasil angket mendapatkan persentase sebesar 70,31\% dengan dikategorikan baik. Hal ini menunjukan bahwa para siswa tidak setuju dengan pernyataan tersebut. Pada pernyataan kelima yaitu saya bisa mendapat materi pembelajaran 
secara daring dengan mudah melalui E-Modul. Pada pernyataan ini mendapatkan persentase sebesar 70,31\% dan dikategorikan baik. Hal ini menunjukan bahwa para siswa setuju dengan pernyataan tersebut. Berdasarkan lima pernyataan tersebut mendapatkan rata - rata persentase sebesar 69,69\%, sehingga masuk dalam kategori baik dalam memenuhi indikator yang ada. Berdasarkan hasil wawancara mengenai tanggapan penerapan E-Modul pada pembelajaran, empat siswa dari kelas tersebut menjawab bahwa penerapan E-Modul sangat membantu dan mempermudah memahami materi pola bilangan. Berdasarkan hasil angket dan wawancara pada siswa kelas VIIIC menunjukan bahwa E-Modul memenuhi tiga indikator dalam aspek kegunaan yaitu mempermudah, memberikan fokus dan membantu proses pembelajaran, yang artinya dari segi kegunaan E-Modul dapat membantu siswa mencapai tujuan pembelajaran yaitu memahami materi. Hal ini sejalan dengan penelitian dari (Nurseto, 2012) penggunaan media pembelajaran yang dirancang dengan baik akan membantu siswa dalam mencapai tujuan pembelajaran, memperlancar proses pembelajaran, dan mengoptimalkan hasil belajar.

Hasil penelitian angket pada aspek kemudahan pengguna terdiri dari lima pernyataan dengan dua indikator, pada pernyataan pertama termasuk dalam pernyataan positif yaitu mudah bagi saya untuk menggunakan E-Modul sesuai yang saya inginkan. Pada pernyataan tersebut respon 32 siswa kelas VIIIC termasuk dalam kategori baik yaitu sebesar 71,09\%. Berdasarkan hasil angket tersebut menunjukan bahwa para siswa setuju dengan pernyataan tesebut. Pada pernyataan yang kedua yaitu saya mengalami kesulitan dalam penggunaan E-Modul. Pada pernyataan ini termasuk dalam pernyataan negatif, dengan persentase respon siswa sebesar $50,00 \%$ dan persentase tersebut masuk dalam kategori cukup baik. Berdasarkan hasil tersebut menunjukan bahwa sebagian besar para siswa tidak setuju dengan pernyataan tersebut. Pada pernyataan yang ketiga yaitu Mudah bagi saya untuk mengakses E-Modul dimana saja dan kapan saja. Pernyataan tersebut mendapatkan persentase dengan kategori baik yaitu sebesar $73,44 \%$. Berdasarkan persentase tersebut menunjukan bahwa para siswa setuju dengan pernyataan tersebut. Pada pernyataan keempat yaitu Saya tidak perlu khawatir jika tidak membawa buku saat pembelajaran daring karena sudah menggunakan E-Modul. Berdasarkan pernyataan tersebut pada hasil angket mendapatkan persentase sebesar 64,06\% dengan dikategorikan baik. Hal ini menunjukan bahwa para siswa setuju dengan pernyataan tersebut. Pada pernyataan kelima yaitu Dengan E-Modul saya tidak kesulitan dalam mencari materi pola bilangan. Pada pernyataan ini mendapatkan persentase sebesar 72,66\% dan dikategorikan baik. Hal ini menunjukan bahwa para siswa setuju dengan pernyataan tersebut. Berdasarkan lima pernyataan pada aspek kemudahan pengguna tersebut mendapatkan rata - rata persentase sebesar $66,25 \%$, sehingga masuk dalam kategori baik. Berdasarkan hasil wawancara mengenai kemudahan penggunaan E-Modul pada pembelajaran oleh, empat siswa dari kelas tersebut menjawab bahwa penggunaan E-Modul mudah dan empat siswa juga mengatakan bahwa mereka tidak keberatan menggunakan E-Modul dalam pembelajaran. Berdasarkan hasil angket dan wawancara pada siswa kelas VIIIC menunjukan bahwa penggunaan E-Modul sebagai media pada pembelajaran, mudah digunakan oleh siswa untuk memahami materi pola bilangan di masa pandemi covid-19. E-Modul tersebut dapat diakses melalui media elektronik seperti HP, laptop, komputer. Oleh karena itu, dengan kemudahan akses E-Modul akan meningkatkan semangat siswa dalam belajar materi pola bilangan lebih dalam sehingga meningkatkan pemahaman siswa. Hal ini sejalan dengan pendapat (Prasetyo et al., 2015) yaitu penerapan dan 
penggunaan media pembelajaran berbasis android sangat mendukung pembelajaran yang berpusat pada siswa (student centered) dan akan menumbuhkan minat siswa untuk berusaha belajar mendalam.

Hasil penelitian angket pada aspek tampilan media terdiri dari lima pernyataan, pada pernyataan pertama termasuk dalam pernyataan positif yaitu kualitas tampilan E-Modul menarik sehingga membantu saya dalam memahami materi pola bilangan. Pada pernyataan tersebut respon 32 siswa kelas VIIIC termasuk dalam kategori baik yaitu sebesar 71,88\%. Berdasarkan hasil angket tersebut menunjukan bahwa para siswa setuju dengan pernyataan tesebut. Pada pernyataan yang kedua yaitu Kualitas gambar dan ilustrasi E-Modul tidak menarik sehingga tidak membantu saya dalam memahami materi pola bilangan. Pada pernyataan ini termasuk dalam pernyataan negatif, dengan persentase respon siswa sebesar $62,50 \%$ dan persentase tersebut masuk dalam kategori baik. Berdasarkan hasil tersebut menunjukan bahwa sebagian besar para siswa tidak setuju dengan pernyataan tersebut. Pada pernyataan yang ketiga yaitu Kesesuaian jenis dan ukuran huruf sesuai dengan materi yang disampaikan. Pernyataan tersebut mendapatkan persentase dengan kategori baik yaitu sebesar 71,09\%. Berdasarkan persentase tersebut menunjukan bahwa para siswa setuju dengan pernyataan tersebut. Pada pernyataan keempat yaitu tampilan pada E-Modul tidak menghabiskan memori pada HP. Berdasarkan pernyataan tersebut pada hasil angket mendapatkan persentase sebesar 69,53\% dengan dikategorikan baik. Hal ini menunjukan bahwa para siswa setuju dengan pernyataan tersebut. Pada pernyataan kelima yaitu penggunaan E-Modul tidak menghabiskan banyak kuota internet saya. Pada pernyataan ini mendapatkan persentase sebesar $67,97 \%$ dan dikategorikan baik. Hal ini menunjukan bahwa para siswa setuju dengan pernyataan tersebut. Berdasarkan lima pernyataan pada aspek kemudahan pengguna tersebut mendapatkan rata - rata persentase sebesar 68,59\%, sehingga masuk dalam kategori baik. Berdasarkan hasil wawancara mengenai tampilan E-Modul pada pembelajaran oleh tiga siswa menjawab tampilan E-Modul menarik, mudah dipahami sehingga tidak bosan mempelajari materi pola bilangan, satu siswa menjawab tampilan E-Modul simpel tetapi kurang menarik. Berdasarkan hasil angket dan wawancara pada siswa kelas VIIIC menunjukan bahwa tampilan E-Modul sebagai media pada pembelajaran menarik, simpel dan mudah dipahami. Dengan tampilan yang menarik pada media pembelajaran maka akan meningkatkan motivasi dan hasil belajar siswa. Hal ini sejalan dengan penelitian (Resiani et al., 2015) mengemukakan kejelasan kemenarikan tampilan fisik sangat mempengaruhi proses pembelajaran, semakin menarik tampilan multimedia maka siswa termotivasi untuk belajar sehingga mempengaruhi hasil belajar siswa.

Hasil penelitian angket pada aspek kepuasan siswa terdiri dari lima pernyataan, pada pernyataan pertama termasuk dalam pernyataan negatif yaitu adanya E-Modul membuat saya kesulitan dalam menerima pembelajaran. Pada pernyataan tersebut respon 32 siswa kelas VIIIC termasuk dalam kategori baik yaitu sebesar 67,97\%. Berdasarkan hasil angket tersebut menunjukan bahwa para siswa tidak setuju dengan pernyataan tesebut. Pada pernyataan yang kedua yaitu adanya E-Modul membantu saya dalam berinteraksi dengan siswa lain maupun dengan guru saat pembelajaran berlangsung. Pada pernyataan ini termasuk dalam pernyataan positif, dengan persentase respon siswa sebesar $71,88 \%$ dan persentase tersebut masuk dalam kategori baik. Berdasarkan hasil tersebut menunjukan bahwa sebagian besar para siswa setuju 
dengan pernyataan tersebut. Pada pernyataan yang ketiga yaitu E-Modul tidak mendukung dalam proses Pembelajaran daring. Pernyataan tersebut merupakan pernyataan negatif, mendapatkan persentase dengan kategori baik yaitu sebesar $68,75 \%$. Berdasarkan persentase tersebut menunjukan bahwa para sebagian besar siswa tidak setuju dengan pernyataan tersebut. Pada pernyataan keempat yaitu dengan menggunakan E-Modul saya tidak bisa mengerjakan tugas dengan mudah. Berdasarkan pernyataan tersebut pada hasil angket mendapatkan persentase sebesar 65,63\% dengan dikategorikan baik. Hal ini menunjukan bahwa para siswa tidak setuju dengan pernyataan tersebut. Pada pernyataan kelima yaitu E-Modul membuat pembelajaran tetap berjalan pada masa pandemi covid-19. Pada pernyataan ini mendapatkan persentase sebesar 78,13\% dan dikategorikan baik. Hal ini menunjukan bahwa para siswa setuju dengan pernyataan tersebut. Berdasarkan lima pernyataan pada aspek kepuasan siswa tersebut mendapatkan rata - rata persentase sebesar 70,47\%, sehingga masuk dalam kategori baik. Berdasarkan persentase hasil angket pada aspek kepuasan siswa yang telah diperoleh dapat disimpulkan bahwa siswa puas terhadap penggunaan E-Modul dalam proses pembelajaran pada materi pola bilangan, karena dengan E-Modul pembelajaran masih tetap bisa berjalan dan tidak mengalami kesulitan. Hal ini berarti proses pembelajaran dilakukan dengan baik sehingga kepuasan siswa terhadap media pembelajaran akan meningkatkan pemahaman siswa pada materi pola bilangan. Hal ini sejalan dengan penelitian dari (Putra, 2019) karena jika proses pembelajaran dilakukan dengan kualitas yang baik, kepuasan siswa akan meningkat disertai dengan hasil belajar yang meningkat pula.

Hasil penelitian angket pada aspek materi terdiri dari lima pernyataan, pada pernyataan pertama termasuk dalam pernyataan positif yaitu materi yang terdapat dalam modul sesuai dengan materi pola bilangan untuk kelas VIII. Pada pernyataan tersebut respon 32 siswa kelas VIIIC termasuk dalam kategori baik yaitu sebesar 75,78\%. Berdasarkan hasil angket tersebut menunjukan bahwa para siswa setuju dengan pernyataan tesebut. Pada pernyataan yang kedua yaitu materi pola bilangan yang ada pada E-Modul lengkap dengan berbagai latihan soal. Pada pernyataan ini termasuk dalam pernyataan positif, dengan persentase respon siswa sebesar $75,00 \%$ dan persentase tersebut masuk dalam kategori baik. Berdasarkan hasil tersebut menunjukan bahwa para siswa setuju dengan pernyataan tersebut. Pada pernyataan yang ketiga yaitu Gambar pada E-Modul jelas dan sesuai dengan dapat jelas dipahami. Pernyataan tersebut mendapatkan persentase dengan kategori baik yaitu sebesar 69,53\%. Berdasarkan persentase tersebut menunjukan bahwa para siswa setuju dengan pernyataan tersebut. Pada pernyataan keempat yaitu Penjelasan materi pada E-Modul sulit dipahami. Berdasarkan pernyataan tersebut pada hasil angket mendapatkan persentase sebesar 64,06\% dengan dikategorikan baik. Hal ini menunjukan bahwa sebagian besar para siswa tidak setuju dengan pernyataan tersebut. Pada pernyataan kelima yaitu Saya akan langsung paham maksud dari gambar dan tabel yang terdapat pada E-Modul. Pada pernyataan ini mendapatkan persentase sebesar 65,63\% dan dikategorikan baik. Hal ini menunjukan bahwa para siswa setuju dengan pernyataan tersebut. Berdasarkan lima pernyataan pada aspek materi tersebut mendapatkan rata - rata persentase sebesar 70,00\%, sehingga masuk dalam kategori baik. Berdasarkan wawancara mengenai kesesuaian materi pada E-Modul dalam pembelajaran oleh tiga siswa menjawab penggunaan E-Modul dapat membantu memahami materi pola bilangan di masa pandemi Satu siswa menjawab penggunaan E-Modul lumayan membantu memahami materi pola bilangan di masa 
pandemi. Berdasarkan hasil angket dan hasil wawancara kepada siswa kelas VIII disimpulkan bahwa pada penerapan E-Modul tersebut diperoleh kesesuaian dan kelengkapan materi sehingga membuat siswa termotivasi untuk mempelajari dan mencari materi pola bilangan lebih dalam sehingga paham akan materi tersebut. Hal ini sejalan dengan penelitian dari (Suarsana \& Mahayukti, 2013) dengan cakupan materi yang eksploratif akan mendorong mahasiswa dalam mencari informasi sebanyak - banyaknya dari berbagai sumber. Metode wawancara pada penelitian ini diberikan melalui platform Google Form dan ditujukan pada siswa kelas VIII C dengan mengambil 4 sampel dari 32 siswa dengan cara purposive sampling dilanjut dengan random sampling dengan teknik undian. Berikut hasil dari wawancara :

Tabel 7. Hasil Wawancara Siswa

\begin{tabular}{|c|c|c|}
\hline No & Petanyaan & Deskripsi Jawaban \\
\hline 1. & $\begin{array}{l}\text { Bagaimana tanggapan anda mengenai } \\
\text { penggunaan E-Modul dalam kegiatan } \\
\text { pembelajaran pada materi pola } \\
\text { bilangan? }\end{array}$ & $\begin{array}{l}\text { Empat siswa menjawab sangat } \\
\text { membantu dan mempermudah } \\
\text { memahami materi pola bilangan }\end{array}$ \\
\hline 2. & $\begin{array}{l}\text { Menurut anda, apakah penggunaan E- } \\
\text { Modul dalam pembelajaran mudah? }\end{array}$ & $\begin{array}{l}\text { Empat siswa menjawab } \\
\text { penggunaan } \quad \text { E-Modul dalam } \\
\text { pembelajaran mudah }\end{array}$ \\
\hline 3. & $\begin{array}{l}\text { Apakah anda merasa keberatan saat } \\
\text { pembelajaran menggunakan E- } \\
\text { Modul? }\end{array}$ & $\begin{array}{l}\text { Empat siswa menjawab tidak } \\
\text { merasa keberatan } \\
\text { pembelajaran menggunakan E- } \\
\text { Modul }\end{array}$ \\
\hline 4. & $\begin{array}{l}\text { Menurut anda, Bagaimana tampilan } \\
\text { E-Modul pada materi pola bilangan? }\end{array}$ & $\begin{array}{l}\text { - Tiga siswa menjawab tampilan } \\
\text { E-Modul menarik, mudah } \\
\text { dipahami sehingga tidak bosan } \\
\text { mempelajari materi pola } \\
\text { bilangan } \\
\text { - Satu siswa menjawab tampilan } \\
\text { E-Modul simpel dan tetapi } \\
\text { kurang menarik }\end{array}$ \\
\hline 5. & $\begin{array}{l}\text { Menurut anda, apakah penggunaan E- } \\
\text { Modul dapat membantu anda dalam } \\
\text { memahami materi pola bilangan } \\
\text { selama pembelajaran di masa } \\
\text { pandemi? }\end{array}$ & $\begin{array}{l}\text { - Tiga siswa menjawab } \\
\text { penggunaan E-Modul dapat } \\
\text { membantu memahami materi } \\
\text { pola bilangan di masa pandemi } \\
\text { - Satu siswa menjawab } \\
\text { penggunaan E-Modul lumayan } \\
\text { membantu memahami materi } \\
\text { pola bilangan di masa pandemi }\end{array}$ \\
\hline
\end{tabular}

Berdasarkan hasil dari angket dan wawancara diperoleh respon siswa terhadap penerapan EModul dalam meningkatkan pemahaman siswa pada materi pola bilangan termasuk dalam kategori baik.

\section{Kesimpulan}

Berdasarkan hasil dari penelitian dan pembahasan disimpulkan bahwa dalam pembuatan media pembelajaran berupa E-Modul diperlukan beberapa tahapan yaitu tahapan pendefinisian yang terdiri dari empat analisis antara lain: analisis peserta didik, analisis materi, analisis tugas, dan analisis 
tujuan pembelajaran. Penganalisisan tersebut dilakukan agar isi dari E-Modul dapat disesuaikan dengan sistem pembelajaran selama pandemi. Tahapan yang kedua yaitu perancangan yang terdiri dari tiga langkah yaitu pemilihan media, pemilihan dan perancangan format, dan evaluasi. Pada penelitian ini media yang digunakan adalah fliping book dengan rancangan format yang sudah disesuaikan dan dievaluasi sehingga layak untuk diberikan kepada peserta didik. Tahap yang terakhir yaitu tahapan penyebaran, dengan menyebarkan E-Modul yang sudah dievaluasi kepada peserta didik.

Berdasarkan hasil angket respon siswa disimpulkan bahwa analisis keefektivan penerapan EModul dalam meningkatkan pemahaman siswa kelas VIII pada materi pola bilangan selama pandemi covid-19 dapat dilihat dari lima aspek dimana diperoleh persentase rata - rata pada tiap aspek yaitu 69,69\% pada aspek kegunaan, 66,25\% pada aspek kemudahan pengguna, 68,59\% pada aspek tampilan media, 70,47\% pada aspek kepuasan siswa, dan 70,00\% pada aspek materi. Seluruh persentase mendapatkan kategori baik. Hasil metode Wawancara pada siswa dalam penelitian memperoleh respon baik dari siswa. Maka berarti penerapan E-Modul dalam meningkatkan pemahaman pada materi pola bilangan untuk siswa kelas VIII dinilai efektif

\section{Daftar Pustaka}

Abidin, Z. (2016). Penerapan Pemilihan Media Pembelajaran. Edcomtech, 1(1), 9-20.

Alfalathi, S. A., Fanzy, B. Y., \& Muharomah, E. Y. (2020). Keterampilan Sosial Siswa Smp Negeri 27 Bekasi. Jurnal Obor Penmas, 3(1), 193.

Mahnun, N. (2012). Media Pembelajaran (Kajian terhadap Langkah-langkah Pemilihan Media dan Implementasinya dalam Pembelajaran). An-Nida', 37(1), 27-35.

Marion, Zulkardi, \& Somakim. (2015). Desain Pembelajaran Pola Bilangan Menggunakan Model Jaring Laba-Laba Di Smp. Jurnal Kependidikan, 45(1), 44-61. https://doi.org/10.21831/jk.v45i1.7185

Naserly, M. K. (2020). Implementasi Zoom, Google Classroom, Dan Whatsapp Group Dalam Mendukung Pembelajaran Daring (Online) Pada Mata Kuliah Bahasa Inggris Lanjut. Journal of Chemical Information and Modeling, 4(2), 155-165. https://jurnaldikpora.jogjaprov.go.id/index.php/jurnalideguru/article/view/129

Nur, R. (2013). HAKIKAT PENDIDIKAN MATEMATIKA Oleh: Nur Rahmah. Al-Khawarizmi, 2 , $1-10$.

Nurseto, T. (2012). Membuat Media Pembelajaran yang Menarik. Jurnal Ekonomi Dan Pendidikan, 8(1), 19-35. https://doi.org/10.21831/jep.v8i1.706

Prasetyo, E. B. (2017). Penerapan Model Pembelajaran Savi Menggunakan Media Maket Pada Mata Pelajaran Menggambar Konstruksi Atapdi Kelas Xii-Tgb 2 Smk Negeri Kudu. Jurnal Kajian Pendidikan Teknik Bangunan, 2(2/JKPTB/17).

Prasetyo, Y. D., Yektyastuti, R., Solihah, M., Ikhsan, J., \& Sugiyarto, K. H. (2015). Pengaruh Penggunaan Media Pembelajaran Kimia Berbasis Android Terhadap Peningkatan Motivasi. Prosiding Seminar Nasional Pendidikan Sains (SNPS), November, 252-258.

Rat Dwiyana Putra, I. D. G. (2019). Peran Kepuasan Belajar Dalam Mengukur Mutu Pembelajaran Dan Hasil Belajar. Jurnal Penjaminan Mutu, 5(1), 22. https://doi.org/10.25078/jpm.v5i1.756

Resiani, N. K., Gede, A. A. A., \& Jampel, I. N. (2015). Pengembangan Multimedia Pembelajaran Interaktif Pada Mata Pelajaran Ips Siswa Kelas Vii Semester Genap Di Smp N 7 Singaraja Tahun 
Ajaran 2014 / 2015 Jurusan Teknologi Pendidikan Universitas Pendidikan Ganesha digunakan . Media disini sangat penting siswa. E-Journal Edutech Universitas Pendidikan Ganesha, 3(1), $1-10$.

Satriawati, H. (2015). Pengembangan E-Modul Interaktif Sebagai Sumber Belajar Elektronika Dasar Kelas X SMKN 3 Yogyakarta. Universitas Negeri Yogyakarta.

Suarsana, I. M., \& Mahayukti, G. A. (2013). Pengembangan E-Modul Berorientasi Pemecahan Masalah Untuk Meningkatkan Keterampilan Berpikir Kritis Mahasiswa. Jurnal Nasional $\begin{array}{lllll}\text { Pendidikan Teknik Informatika } & \text { (JANAPATI), } & 2(3), & \end{array}$ https://doi.org/10.23887/janapati.v2i3.9800

Utami, R. E., Nugroho, A. A., Dwijayanti, I., \& Sukarno, A. (2018). Pengembangan E-Modul Berbasis Etnomatematika Untuk Meningkatkan Kemampuan Pemecahan Masalah. JNPM (Jurnal Nasional Pendidikan Matematika), 2(2), 268. https://doi.org/10.33603/jnpm.v2i2.1458 